Journal of Social and Development Sciences

Vol. 4, No. 4, pp. 185-192, Apr 2013 (ISSN 2221-1152)

\title{
HRM vs Industrial Relations: a Comparative and Theoretical Evaluation of Two Disciplines
}

\author{
Cemallyem, Yasemin Ozdemir \\ Sakarya University, Turkey \\ ciyem@sakarya.edu.tr
}

\begin{abstract}
In recent years, significant changes are experienced in practice as well as theory to the field of industrial relations. Globalization, rapid progress in the field of technology, such as reduction of the importance of class conflict factors affect the industrial relations field. In this paper, the perspectives of (IR) Industrial Relations and (HRM) Human Resource Management disciplines within the framework of the text books compared. During the first part of this comparison information about the conceptual framework of the discipline of industrial relations. In the second part referred to the concept of human resource management. In the last chapter of human resource management and industrial relations textbooks, certain themes will be examined in a comparative framework. Thus, the perspectives of the two disciplines against each other is aimed.
\end{abstract}

Keywords: HRM, IR, HRM Textbooks

\section{Introduction}

In developed economies many industrial problems stem from prejudice, resistance to change and restricted communications between employers and employees. Industrial relations system with the transition from an agricultural society to industrial society, from the last quarter of the 20th century, which became a global influence of the neo-liberal policies, has engaged in a process of radical transformation. The transition from industrial to information society services sector and the industrial sector towards the mobility of the labour force in the world that continued until the change process caused a change in the structure of traditional industrial relations system. The effect of all these changes and the transformation of national and international competition have increased and quality improvement organizations to ensure their superiority over its competitors, such as increasing productivity and decreasing costs have entered into a new quest. The most important actor in the focus of this new way of searching for all human beings. During 1950's HRM was seen as a part of industrial relations. After 1960's HRM and industrial relations tended to develop as two different areas: industrial relations are narrowly focused on unions and labour-management relations and HRM is focused on the functional parts of employment management. IR and HRM differentiation is parallel to work economist and scientists from management and behaviour sciences. So, in this study, the difference between industrial relations and human resource management disciplines will be discussed in accordance with the contents of textbooks in USA, Europe and Turkey.

\section{Industrial Relations Background}

Industrial relations is a multidisciplinary field that studies the employment relationship (Kaufmanand Bruce; 2004). Industrial relations is increasingly being called employment relations or employee relations, therefore the importance of non-industrial employment relationships this move is sometimes seen as further broadening of the human resource management trend (Banfield and Kay; 2008).Postindustrial transformation process and that with the change in labour force quality, as well as the importance of human resource management field to gain reduces the effectiveness of industrial relations. Industrial relations means by which the various interests involved in the labour market are accommodated, primarily for the purpose of regulating employment relationships. Industrial relations are also a multidisciplinary field that studies the collective aspects of the employment relationship. There are 3 main different perspectives on Industrial Relations, as mentioned below.

Different perspectives on IR: 
Table 1: Industrial Relations Different Perspectives

\begin{tabular}{ll}
\hline Pluralist & $\begin{array}{l}\text { Pluralists see conflict as inevitable because, to cite, various organizations } \\
\text { participate in determining the rules of employment. } \\
\text { Tnitarist }\end{array}$ \\
The unitary view is that there is an identity of interest between employer and \\
employee. \\
Radical/Marxist \\
$\begin{array}{l}\text { Radical, approach developed as a critique, or in the significant case of an auto- } \\
\text { critique, of pluralism. }\end{array}$ \\
Reference: Paul Edward (2003:10-11), Industrial Relations, Theory and Practice, Blackwell Publishing
\end{tabular}

Industrial relations system, formed by arising new employment types with transition from agricultural society to industrial society, appearing as a result of desire to arrange labour relations, entered to a radical transformation process with the effect of neoliberal policies which has gained a global characteristic after the last quarter of 20th century. Exclusively, in contemplation that the workforce with its increasing qualification, has obtained individual bargaining power in the new society, wide spreading of the thought that there is no need for players of the system-especially labour unions- in arranging labour relations, has caused to the birth of a new model -Human Resources Management-In fact, the importance of industrial relations the most important reason for the reduction of a serious decline of unionism and workers' organizations can be shown to be. However, Yildirim's (1997), as expressed to decline to check this in the future of industrial relations or the form of industrial relations in the union will wrap, or vanished, and the human resources management will be left to claim is incorrect. Therefore, a dynamic sub-system of society as "Industrial Relations" at the past, today and future to analyze the "Human Resources" and "Strategic Human Resources" approach" in the role of Industrial Relations will allow us to understand better. In particular, in the 1970s, World War II until the end of the ongoing period of high employment, growth, industry relations, as well as reconciliation and the trade union organizations and collective bargaining it is possible to see the development of. However, these positive statements in the first quarter of the 1970s economic crisis occurring in the unstable structure were replaced. Especially with the increase in the unemployment rate and employment to the unemployed masses "Atypical working" formats emerged. Moreover, the advanced technology brought a change in the workforce profile. Employers and trade unions in the 1980s are coming to the economic and social life and the effects vary with the location, it is possible to see the trade unions started to weaken (Uckan and Kağnıcıoğlu, 2004). In particular, the process of restructuring in the economy and technological progress by now lost the importance of relationships corporatist individual interests to the fore an understanding that reveals the judges. This change in the structure of collective bargaining itself is felt. National-level collective bargaining in the sense of place to a configuration requires a more micro level, was replaced by the establishment.

Once upon a time, massive blue collar and more humane work / life conditions to ensure that come together as created and then this combination political field into the other developments with the welfare state the path to the layer of trade unions to the state when look at it; unions now and against capital as well as the political scene when considered What is the power! Is seen as one raised for organizations that are afraid of fashion (Man and Iyem, 2008). This component consists of the industrial relations system, developed in parallel with the very nature of the matter is lost. Areas where the collective consciousness of individuals focused on the future of industrial relations in many different scenarios were produced. At present, industrial relations and are opposed to each other HRM's and HRM's development of industrial relations will disappear with you in the direction of HRM and Industrial Relations that the competitors to each other, complement each other in the direction where there are different opinions (Tokol, 2001). In fact Tokol (2001) expressed as a paradox in the process, business or business to the worker's trade union decision-making power is the closest. The same paradoxical problem, create a theoretical dimension to the educational process is also possible to downmix. Thus from Personnel Management to Human Resources together with the transition to the Industrial Relations The importance of teaching reading based resources are the basis of how the changes brought?, Western literature with the source in Turkey between sources of Industrial Relations The importance of what similarities or differences are there? This also prepares the ground for the transition of Human Resources Management as the inevitable result of technological development, with the transition from labor-intensive technology, capital-intensive technology, on one hand, on the other hand the workers employed in the nature of the worker changes taking place machines. Both the world economy, as well as the structural changes in the national economies, micro-technology that was pioneered in the business world, the demand for high quality 
components increases. In the business world the growing demand for high-skilled workers has also led to unemployment.

HRM Perspective: Human resources are an organization's greatest assets because without them, everyday business functions such as managing cash flow, making business transactions, communicating through all forms of media, and dealing with customers could not be completed. Human resources and the potential they possess are key drivers for an organization's success (Haslinda, 2009). Human resources management, appearing with post-industrial transformation process as a new face of industrial relations, is used as a tool for indirect relations between employer and employee thus labour unions are seen like outdated organisations, belonging to 19th century, especially in multinational corporations (Işık, 2009). In recent years HRM has been a wide repercussion a management approach to working life. In order to examine the terms for HRM, it will be useful to define what HRM is a process of managing human talents to achieve organisation's objective. Human resource management is about managing people so that businesses are competitive and successful. The human resource management (HRM) function of an organisation manages the individual aspects of the employment relationship - from employee recruitment and selection to international employment relations, salaries and wages. Before the HRM we can see Personal Management in all organizations. So what is the different between Personal Management and Human Resource Management? Actually, the rebranding for the term PM to HRM was argued as due to the evolvement and changes in the world of management and therefore a new term would seem appropriate to take new ideas, concepts and philosophies of human resources (Noon, 1992, Armstrong 2000, cited in Haslinda, 2009). HRM is simply a trendy label used by personnel specialists to re-badge established practises (Armstrong, 1987, cited in Ezzamel, Lilley, Wilkinson, Willmott, 1996). Indeed, some writers commented that there are 'little differences' between (PM) Personnel Management and (HRM) Human Resource Management and it has been criticized as pouring 'old wine into new bottle' with a different label (Legge, 2005). Whether HRM was considered to be different to personnel management - there is a continuous debate on the meaning and practice of HRM compared with PM (Legge, 2005).In part to reflect these, none outline approaches to the management of employees in the mid1980s. Therefore, the term HRM gradually tended to replace the term PM (Lloyd and Rawlinson, 1992). However, writers argued that the term HRM has no appreciable difference from PM as they are both concerned with the function of obtaining, organizing, and motivating human resources required by organizations. At the same time, writers are defining the terms HRM and PM in many different ways (Beer and Spector, 1985).

As one of Personnel Manager said when commenting upon the change of name her department from Personnel to Human Resource Management: "People thought it was just a name change but it was much more than that. It was a conscious change in the focus of the department. Before the change, it had a strong welfare role... and really there was no concept of business need or business goals... My current boss is involved much more in the strategic management group whereas the previous guy wasn't involved at all" (Personnel Management, Financial Services, Ezzamel, Lilley, Wilkinson, Willmott, 1996). Especially the 1980 concept of strategic HRM emerged (for example Schuler 1989; Boxall 1992; Bratton and Gold 1999). Increased competition in both national and global arenas has forced managers to reconsider the management of all resources within the organisation, paying specific attention to the effective management of the human resource, leading to declarations such as "people are our most valuable asset". This reappraisal of the techniques used to manage employees within an organisation has led to the development of various approaches towards human resource management: for example the instrumental approach which focuses on the so-called hard HR areas such as HR planning where human resources are viewed as "rationally" as any other economic factor; and the humanistic approach emphasising the socalled softer aspects of HRM such as organisational culture and employee commitment (Goss, 1994). The shift from traditional personnel management towards a more sophisticated human resource management has been reported extensively in recent years (Storey 1989; Legge 1989; Sisson 1989; Guest 1989; Beer et al. 1985). Guest (1993) identifies the central levers for HRM as selection, training and rewards. It is widely accepted, however, that the main features of a human resource management network include additional features such as welfare, trade unions, assessment, employee involvement and equal opportunities. In the Europe and USA the transformation required a process based in the improvements within HRM practices but in Turkey the transformation remained superficial limited to the name change from personnel management to HRM. Furthermore the transformation to strategic HRM has been seen as luxury for the Turkish companies (Bayraktaroglu, 2006). Literally strategic HRM includes four dimensions (Bratton and Gold 1999): reengineering, leadership, workplace learning and labour unions. It can be claimed that these dimensions will let us improve HRM strategically and hence overcome so-called 
shortfalls of HRM. There may be different mechanisms to provide the balance of achieving the desired results: HRM view and IR view mainly structured around the idea of labour unions. Creation of "us" and "them" as competing parties this process may become more unproductive in terms of performance standards.

\section{HRM Textbooks in USA, Europe and Turkey}

Aim of the Research: In this study, it is aimed to evaluate the HRM and IR academic thoughts comparatively by analysing the IR and HRM common concepts and issues in IR and HRM books in Turkey, USA and Europe. In other words theoretical framework of two related areas will be analysed comparatively. Therefore, IR has an important effect on the evolution of HRM.

Method of the Research: According to the aim of this research, the IR and HRM textbooks published in Turkey, USA and Europe are analysed using the content analysis to evaluate theoretical interaction between IR and HRM comparatively (Luborsky, 1994). The textbooks are the basic textbooks in IR literature (Purcell, 1981; Salamon, 1987; Ferner and Hyman, 1992; Salamon, 2000; Edwards, 2003) and in HRM literature (Beardwell and Holden, 1994; Bratton and Gold, 1999). In this context, the context of 9 books published in Turkey between 1980-2009 and 10 HRM books published in USA and Europe between 1974-2009 are analysed by using the frequency and significance analysis.

Discussion and Concluding Thoughts: In this section the findings of our research will be indicated in two parts: the findings about HRM books published in Turkey, USA and Europe.

Table 2: The findings about HRM books published in USA and Europe are summarized below

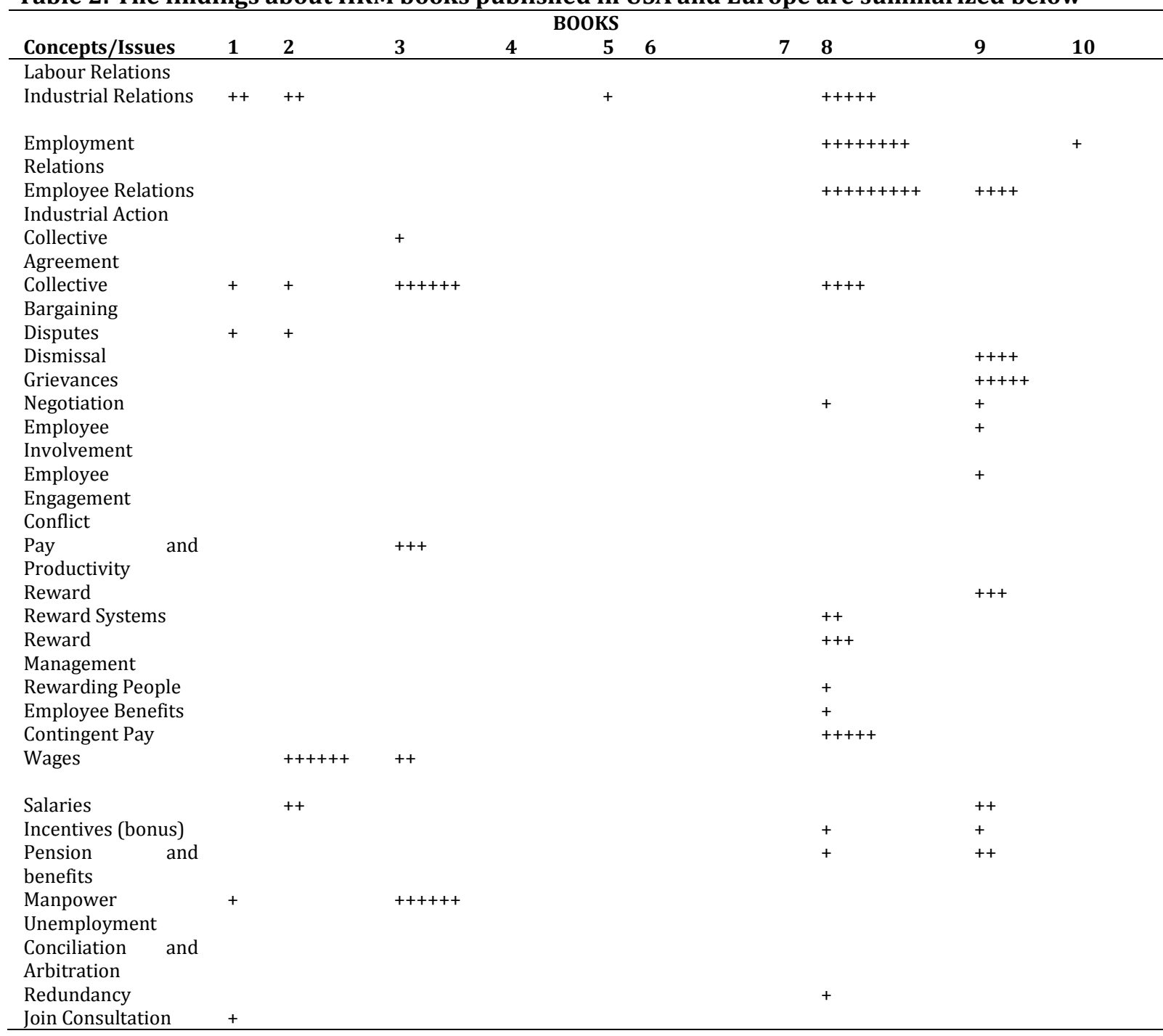




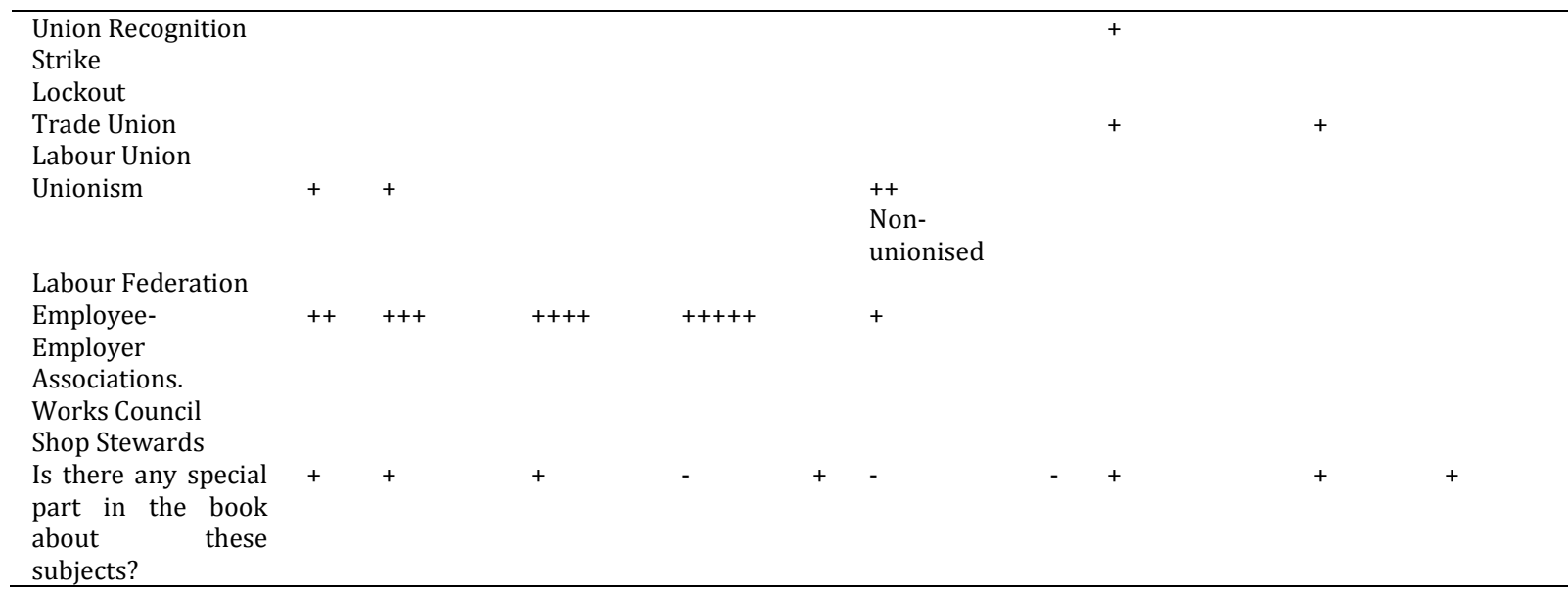

According to the table above;

- Seven HRM books have a special section about the issues related with IR.

- The issues like labour relations, industrial action, conflict, unemployment, conciliation and arbitration, strike, lockout, labour union, labour federation, work councils and shop stewards are not mentioned in any HRM books.

- Unionism is mentioned in only two HRM books and one of these books has a part named "nonunioniesd".

- Labour union is not mentioned in any book and also trade union is only mentioned in one book.

- Issues like industrial relations, employee relations, and employment relations are mentioned more in the books after the year 2005. And also in these books the issues related with IR are mentioned more.

- The issues related with reward systems are mentioned in different concepts like reward management, pay, wage, salary, benefits mostly earlier and latest HRM books.

- $\quad$ And although trade unions are defined as a dimension of strategic HRM (Bratton and Gold, 1999; Bayraktaroğlu, 2002a). In the last book, which is part of SHRM literature, unions are not mentioned in this book.

The subjects in industry relations have been changed as the time passes. The first three books emphasize the importance of collective bargaining, wages and employee/employer associations because most of the companies were unionised. However, we don't see these subjects/chapters in more recently published text books because weakened labour union bargaining power and chancing collective bargaining strategies have contributed to this result. On the other hand, we started seeing that recently published books have started giving place to non-unionization. Some of the union efforts there such as wages, employee labour associations, pay and productivity and disputes.

Table 3: The findings about Turkish HRM books ( $8^{\text {th }}$ and $9^{\text {th }}$ ones are SHRM books) are summarized below

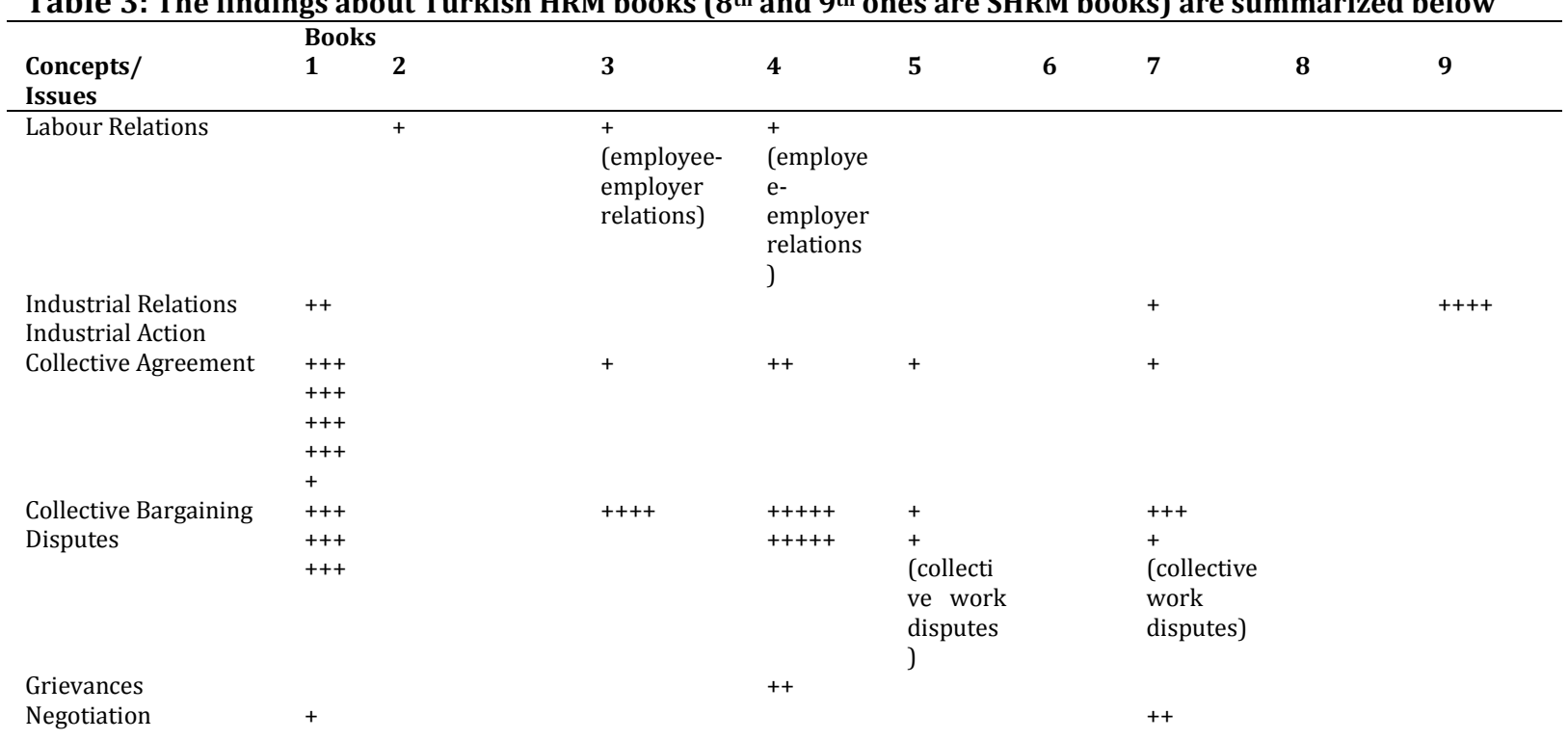




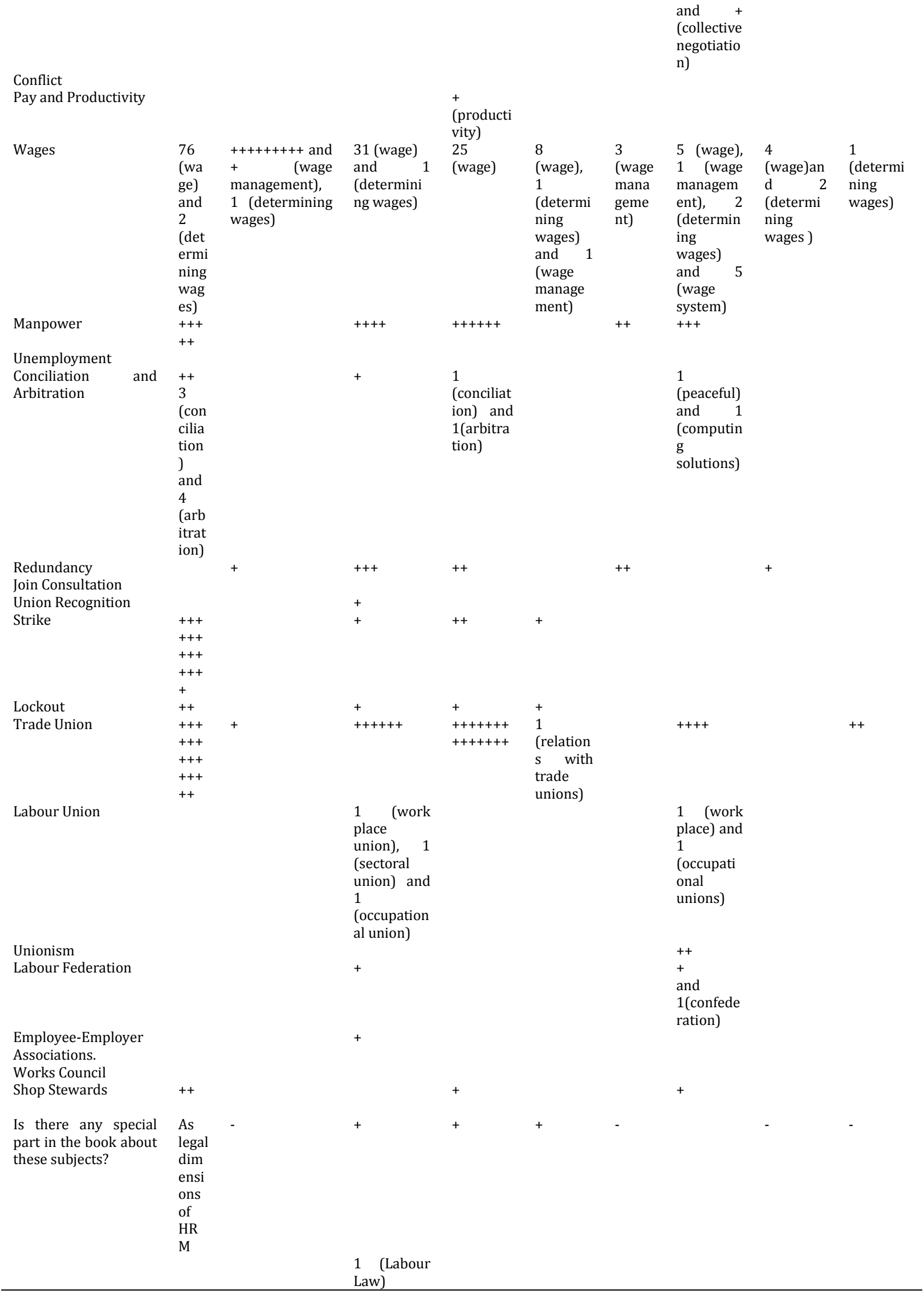

As it is seen from the table only 3 HRM books have a special part named industrial relations and all the HRM and SHRM books mention at least 2 concepts about IR. The most mentioned concept is about wages 
and the second one is about trade unions. It can be said that although IR is an important area in the development of HRM, the concepts/issues about IR do not have an important place HRM books so in HRM literature. Generally the idea of HRM model in Turkey is the opposition of classical industrial relations and collective bargaining agreement and it is argued that HRM methods and policies are developed prove the interest of personnel's good and higher life standards by the management. However, there seems to be a dilemma between the HRM and IR understandings for the organisations. This feature of HRM has had some big effects from the views of political and legal developments, decrease of the membership of labour unions and the governments in USA and the Europe. The labour unions' success can only be possible if they can achieve to adopt the developments in innovative management techniques. Now employees and employers have to face the difficulties of business world together. Instead of wage trade unions the view which supports company's success, competition and employing possibilities is getting stronger. These unions have to look over their roles in business world and adaptive themselves to new developments to survive in today's world. As a result, this process is representing an important stage for developing strategically HRM in Turkey. Our research findings indicate that the dilemma between HRM and IR disciplines are to be faded away as the objectives of both sides are harmonised as the current conditions forced them to cooperate.

\section{References}

Bayraktaroğlu, S. (2002). Stratejik Olan veOlmayanInsan Kaynakları Yonetimi, Beta Yayınları, Istanbul. Bayraktaroglu, S. (2006). Human Resources Management. Sakarya, Adapazarı.

Banfield, P. \& Kay, K. (2008). Introduction to Human Resource Management. Oxford University Press.

Beardwell, I. \& Holden, L. (1994). Human Resource Management (A Contemporary Perspective), Pitman Publishing, London.

Beer, M., Spector, B., Lawrence, P., Mills, D. \& Walton, R. (1985). HRM: A General Manager's Perspective, Free Press, New York, NY.

Beer, M. \& Spector, B. (1985). Corporate wide transformation in HRM. In Walton R. E. and Lawrence P. R. (eds) HRM: Trends and Challenges. Boston, MA: Harvard University Business School Press.

Bingol, D. (2006). İnsan Kaynakları Yönetimi, Arıkan Yayınları, 6.Baskı, Istanbul.

Boxall, P. (1992). Strategic human resource management: beginnings of a new theoretical sophistication? Human Resource Management Journal, 2(3), 60-79.

Bratton, J. \& Gold, J. (1999). Human Resources Management, London: MacMillan Press.

Edwards, P. (2003). Industrial Relations Theory and Practice, Blackwell Publishing.

Ezzamel, M., Lilley, S., Wilkinson, A. \& Willmott, H. (1996). Practices and Practicalities: Changing Human Resource Management. Human Resource Management Journal, 6(1), 63-80

Ferner, A. \& Hyman, R. (1992). Industrial Relations in the New Europe, Oxford, UK

Guest, D. (1993). Current perspectives on human resource management in the United Kingdom, in Hegewisch, A. and Brewster, C. (Eds), European Developments in Human Resource Management, Kogan Page, London.

Guest, D. (1989). HRM: implications for industrial relations, in Storey, J. (Ed.), New Perspectives on HRM, Routledge, London.

Goss, D. (1994). Principles of Human Resource Management, Routledge, London.

Haslinda, A. (2009). Evolving Terms of Human Resource Management and Development. The Journal of International Social Research, 2(9).

Işık, V. (2009). EndüstriİlişkilerininYeniYüzüİnsanKaynaklarıYönetimi: EmeğiÖrgütsüzleştirmeStratejisi. GaziÜniversitesiÍktisadiveÍdariBilimlerFakültesiDergisi, 11(3), 147 - 176

Kaufman, B. E. (2004). The Global Evolution of Industrial Relations: Events, Ideas, and the IIRA, International Labour Office.

Legge, K. (2005). Human Resource Management: Rhetorics and Realities (Anniversary ed). Basingstoke: Palgrave MacMillan

Legge, K. (1989). Human resource management: a critical analysis, in Storey, J. (Ed.), New Perspectives on Human Resource Management, Routledge, London.

Lloyd, C. \& Rawlinson, M. (1992). New technology and human resource management in Blyton, P. and Turnbull, P. (eds) Reassessing Human Resource Management. London: Sage Publications

Luborsky, M. R. (1994). Qualitative Methods in Ageing Research, Thousand Oaks, C. A: Sage.

Man, F. \& İyem, C. (2008). Türkiye'deSendikalarSiyasetiEtkileyebilir mi? 10. SosyalBilimlerKongresi, ODTÜ, Ankara.

Purcell, J. (1981). Good Industrial Relations Theory and Practice, MacMillan. 
Salamon, W. M. (1987). Industrial Relations: Theory and Practice, UK. Salamon, W. M. L. (2000). Industrial Relations: Theory and Practice, UK

Schuler, R. S. (1989). Strategic human resource management and industrial relations. Human Relations, 42(2), 157-84.

Sisson, K. (1989). Personnel Management in Britain, Basil Blackwell, Oxford.

Storey, J. (1989). New Perspectives on Human Resource Management, London: Routledge.

Tokol, A. (2001). Endüstrilliş̧̧kileriveYeniGelişmeler, Vipaş, Bursa.

Uckan, B. \& Kagnıcıoglu, D. (2004). Endüstrilliş̧kileri, AnadoluÜniversitesi, Eskișehir.

Uyargil, C., Adal, Z., AtaayiI, L., Acar, A., Özçelik, O., Sadullah, Ö., Dündarand, G. \& Tüzüner, L. (2008). İnsanKaynaklarıYönetimi, Beta Yayınları, 3. Baskı, Istanbul.

Yıldırım, E. (1997). EndüstriIlișkileriTeorileri (SosyolojikBirDeğerlendirme), DeğișimYayınları, Sakarya. 